\title{
Tanzimat Döneminde Şahitlerin Tezkiyesi ve Buna Yönelik Eleştiriler*
}

\author{
Melikşah AYDIN \\ Dr. Arş. Gör., Selçuk Üniversitesi Hukuk Fakültesi, Hukuk Tarihi Anabilim Dalı, aydinmeliksah@gmail.com, \\ (Yazar / Corresponding Author)
}

\begin{tabular}{|c|c|}
\hline Makale Bilgileri & ÖZ \\
\hline $\begin{array}{l}\text { Makale Geçmişi } \\
\text { Geliş: 17.04.2021 } \\
\text { Kabul: 18.06.2021 } \\
\text { Yayın: 21.06.2021 } \\
\text { Anahtar Kelimeler: } \\
\text { Şahit, Tezkiye, } \\
\text { Tanzimat dönemi, } \\
\text { Eleştiri, Usul Hukuku. }\end{array}$ & $\begin{array}{l}\text { Davada dinlenecek şahitlerin adil ve güvenilir olup olmadıklarının araştırılması faaliyetine } \\
\text { tezkiye denir. Tezkiye faaliyeti kural olarak davaya bakan hâkim tarafından yapılır. Bu } \\
\text { çalışmada İslam hukukunda ve Osmanlı'da uygulanmış olan tezkiye kurumunun Tanzimat } \\
\text { dönemindeki yansıması incelenecektir. Bu açıdan Tanzimat dönemindeki kanunlardaki } \\
\text { şahitlerin tezkiyesi ile ilgili maddeler incelenecektir. Daha sonra Osmanlı'nın son } \\
\text { döneminde Ceride-i Adliye isimli dergide yayınlanan iki makale 1şığında tezkiye kurumuna } \\
\text { getirilen eleştiriler ele alınıp yorumlanacak, son olarak bu kurumun günümüzde } \\
\text { uygulanabilirliği tartışılacaktır. Bu konu Osmanlı'nın ilk devirlerinden itibaren } \\
\text { mahkemelerde uygulanan şahit tezkiyesinin yaşadığı değişimi göstermesi açısından } \\
\text { önemlidir. Uygulama ve usul açısından Osmanlı'nın kuruluşundan yıkılışına kadar çok } \\
\text { değişim göstermeyen şahit tezkiyesi, devletin son yıllarında eleştirilere konu olmuştur. Bu } \\
\text { eleştiriler tezkiye usulünün reforma ihtiyaç duyduğu temelinde tezahür etmekle beraber, } \\
\text { pozitif hukukumuzda uygulaması bulunmayan kurumun şahitlik deliline sağlayabileceği } \\
\text { faydaları göstermesi açısından önemlidir. }\end{array}$ \\
\hline
\end{tabular}

\section{The "Tezkiye" of The Witnesses in Tanzimat Period and Reviews About It}

\begin{tabular}{ll}
\hline Article Info & ABSTRACT \\
\hline \hline $\begin{array}{l}\text { Article History } \\
\text { Received: 17.04.2021 } \\
\text { Accepted:18.06.2021 } \\
\text { Published:21.06.2021 }\end{array}$ & $\begin{array}{l}\text { The activity of investigating whether the witnesses to be heard in the case are fair and } \\
\text { reliable is called tezkiye. As a rule, the act of tezkiye is carried out by the judge who handles } \\
\text { the case. In this study, the reflection of the tezkiye institution in Tanzimat period will be } \\
\text { examined which applied in Islamic law and the Ottoman Empire. In this respect, the articles } \\
\text { related to tezkiye in the laws of the Tanzimat period, will be examined. Later, in the light of } \\
\text { two articles published in Ceride-i Adliye during the last period of the Ottoman Empire, the } \\
\text { Keywords: }\end{array}$ \\
$\begin{array}{l}\text { Witness, Tezkiye, } \\
\text { Tanzimat period, } \\
\text { Review, Procedure }\end{array}$ & $\begin{array}{l}\text { institution today will be discussed. This issue is important in terms of showing the change } \\
\text { of "tezkiye" of the witnesses applied in the courts since the first periods of the Ottoman } \\
\text { Empire. The "tezkiye" of the witness, which did not change much in terms of practice and } \\
\text { procedure from the foundation of the Ottoman Empire to its collapse, has been the subject } \\
\text { of reviews in the last years of the state. These reviews were manifested on the basis that the } \\
\text { procedure of "tezkiye" needed reform. It is also important in terms of showing the benefits } \\
\text { of the institution which is not applied in our positive law can provide witness evidence.. }\end{array}$
\end{tabular}

Atıf/Citation: Aydın, M. (2021). Tanzimat Döneminde Şahitlerin Tezkiyesi ve Buna Yönelik Eleştiriler, Necmettin Erbakan Üniversitesi Hukuk Fakültesi Dergisi, 4(1), s.206-217.

Plagiarism: Bu makale intihal programında taranmış ve en az iki hakem incelemesinden geçmiştir. // This article has been scanned via a plagiarism software and reviewed by at least two referees.

"This article is licensed under a Creative Commons Attribution-NonCommercial 4.0 International License (CC BY-NC 4.0)"

\footnotetext{
* Bu makale, 12.04.2021 tarihinde, Uluslararası Necmettin Erbakan Hukuk Kongresi'nde tebliğ olarak sunulmuştur.
} 


\section{GíRiș}

İslam Hukukunda davada dinlenecek olan şahitlerin ifadelerinin hükme esas alınabilmesi için şahitlere yönelik yapılması zorunlu bir uygulama olarak öngörülen tezkiye kurumu İslamiyet'in ilk devirlerinden Osmanlı Devleti'nin son dönemine kadar uygulanagelmiştir. Tezkiyenin sadece Tanzimat dönemindeki uygulamasının inceleneceği bu çalışma, zaman içinde eskidiği ve faydasız bir hal aldığı yönünde eleştirilere konu olan tezkiyenin genel görünümüne 1şık tutacak, yapılan eleştirileri değerlendirerek sonuç kısmında pozitif hukukumuzda uygulaması olmayan bu uygulamanın şahitliğe olan güveni artırmaya fayda sağlayıp sağlamayacağı konusunda görüş bildirecektir.

\section{GENEL OLARAK}

Tezkiye kelimesi sözlükte "temizlemek, temize çıkarmak, arıtmak" gibi anlamlara gelmektedir. ${ }^{1}$ Tezkiye işlemi ise bir davada dinlenecek olan şahitlerin adaletli, doğru sözlü ve güvenilir kimseler olup olmadığının araştırılması yani bir nevi güvenilirlik soruşturmasıdır. ${ }^{2}$ Şahitler hakkında ifade veren yani tezkiye işini yapan kimselere de "müzekki” denir. ${ }^{3}$ Müzekkilerin şahitler hakkındaki olumlu görüşlerine yani şahidin şahitlik yapmasına engel bir ahvali olmadığına, doğru sözlü, güvenilir kimselerden olduğunu bildirmesine "ta'dil” buna karşın olumsuz görüş bildirmesine ise "cerh" denir. ${ }^{4}$

Tezkiyenin hangi davalarda gerekli olup hangi davalarda gerekmediği konusunda Hanefi mezhebinin içinde görüş farkları bulunmaktadır. İmam-1 Azam Ebu Hanife'ye göre had ve kısas davaları dışındaki davalarda şahitler, aleyhine ifade verecekleri tarafça ta'n edilmezlerse yani bunların şahitliklerine itiraz edilmezse tezkiye yapılmasına gerek yoktur. Bu şahitlerin adil oldukları ve doğru ifade verdikleri kabul edilir. ${ }^{5}$ Ebu Yusuf ve İmam Muhammed'e göre ise aleyhine ifade verilen tarafça bunların şahitliklerine itiraz edilsin veya edilmesin şahitlerin tezkiye edilmesi gerekir, tezkiyeleri olumlu çıkmadan ifadeleri hükme esas alınamaz. ${ }^{6}$ Şahitlerin şahitliklerine taraflar tarafından itiraz gelirse veya had ve kısas davalarında, tüm âlimlere göre

1 KELKİT, Ömer Arif, “Kur'an'da Tezkiye” Basılmamış Yüksek Lisans Tezi, AÜSBE, Ankara, 1999, s.2; BAŞOĞLU, Tuncay, "Tezkiye”, DİA, C.41, İstanbul, 2012, s.77.

2 BAYINDIR, Abdülaziz, İslam Muhakeme Hukuku Osmanlı Devri Uygulaması, İslami İlimler Araştırma Vakfı Yayınları, İstanbul, 1986, s.181; ATAR, Fahrettin, İslam Yargllama Hukukunun Esaslarl, MÜíFY, İstanbul, 2013, s.179.

3 ATAR, Fahrettin, İslam Adliye Teşkilatı, DİB Yayınları, Ankara, 1991, s.204; ASLAN, Nasi, İslam Yargılama Hukukunda "Şuhudü'l-Hal" Jüri Osmanlı Devri Uygulaması, Beyan Yayınları, İstanbul, 1999, s.39; AYDIN, Melikşah, Klasik Dönem Osmanlı Yargllama Hukukunda Tanıklk, Oniki Levha Yayınc1lık, İstanbul, 2021, s.169.

4 BAYINDIR, s.181; BAŞOĞLU, s.77; MESSICK, Brinkley, "Evidence: From Memory to Archive", Islamic Law and Society, Vol. 9, No. 2, Evidence in Islamic Law (2002), s.239; DOĞAN, Hasan, "İslam Muhakeme Hukukunda Ta“dîl ve Tezkiye", İslam Hukuku Araştırmaları Dergisi, Sy.29, 2017, s.14.

5 SERAHSİ, Ebu Sehl Ebu Bekir Muhammed b. Ahmed, Mebsut, ed. Mustafa Cevat Akşit, Gümüşev Yayınları, İstanbul, 2008, C.16, No:88; MAVSILİ, Abdullah b. Mahmud b. Mevdud, el-İhtiyar li- Ta'lîlî'l Muhtar, çev. Mehmet Keskin, Hikmet Neşriyat, İstanbul, 2013, C.2, s.229; ATAR, 2013, s.179.

6 SERAHSI, C.16, No:113; DAMAD TERCÜMESİ, Mecme'ul Enhur, çev. Mehmet Çelik, Yasin Yayınları, İstanbul, 2011, C.4, s.490; FETAVA-YI HİNDIYYYE, Fetava-yl Alemgiriyye, çev. Mustafa Efe, Huzur Yayınları, İstanbul, 2004, C.7, s.76; ALİ HAYDAR, Hocaeminefendizade, Dürerü'l Hukkam Şerhu Mecelleti'l-Ahkâm, çev. Raşit Gündoğdu-Osman Erdem, DİB Yayınları, 2.Baskı, İstanbul, 2017, C.4, s.3090; ZUHAYLİ, Vehbe, İslam Fikhı Ansiklopedisi, ilmi müşavir Mehmet Emin Saraç, çev. Heyet, Risale Yayınları, İstanbul, 1994, C.8, s.258; HARİIİ, İbrahim Muhammed, el-Kavaidu ve'd Davabitu'l Fikhiyyeti li-Nizami'l Kaza fi'l İslam, Umman, 1999, s.103. 
şahitlerin tezkiye edilmeleri gerekir. ${ }^{7}$ Ebu Hanife ile öğrencileri olan Ebu Yusuf ve İmam Muhammed arasındaki görüş farkı zamanın değişmesi, ahlakın bozulması ve insanların doğru sözlü olduklarına yönelik inancın azalması ile ortaya çıkmıştır. ${ }^{8}$

Tezkiye alenen ve sırren tezkiye olmak üzere ikiye ayrilır. Alenen tezkiyede davanın tarafları, şahitler ve şahitleri tezkiye eden müzekkiler birlikte hazır bulunurlar. ${ }^{9}$ Aleni tezkiye mahkemede yahut mahkeme dışında da yapılabilir. Mahkeme dışında yapılacak olan aleni tezkiyede davanın tarafları, şahitler ve mahkemenin görevlendirdiği memur aracıllğıyla müzekkilerin yanına gidilip müzekkinin beyanları dinlenir, memur da bunu kayda geçer. ${ }^{10}$ Sırren tezkiye ise hâkimin kendisinin bizzat veya görevlendireceği memur aracıllğıyla şahitlerin durumunu gizli olarak müzekkilere sormasıdır. Sırren tezkiyede hâkim mahkemede şahit olarak dinlenecek kişilerin isimlerini, adreslerini ve çalıştıkları yeri öğrenir. Daha sonra şahitleri komşularına, iş arkadaşlarına ve yakın çevresine sorar. Bu sordurma faaliyetini genellikle bir mektup vasıtasıyla yapar. ${ }^{11} \mathrm{Bu}$ soruşturma neticesinde şahitlerin ifadelerinin hükme esas alınıp alınamayacağına karar verir.

Sırren tezkiyenin ilk ortaya çıkışı konusunda tartışmalar bulunmaktadır. Bir görüşe göre bu tür tezkiyeyi ilk olarak dört halife devrinin en meşhur kadılarından Kadı Şureyh uygulamıştır. Rivayete göre Kadı Şureyh şahitlerin güvenilir kimseler olup olmadığını şahitleri tanıyan başka kimselerden gizlice sordurmuştur. Bunun üzerine bazı kimseler Kadı Şureyh'e İslam'da olmayan bir yenilik icat ettiği için eleştiride bulunmuşlardır. Kadı Şureyh ise bu eleştiriye "Insanlar İslam'da olmayan şeyler ortaya çıkarınca ben de bunu çıkarmak zorunda kaldım" diyerek cevap vermiştir. $^{12}$

\section{TANZIMAT DÖNEMINDE TEZKIYYE KURUMU}

\section{A. Mecelle Dışındaki Kanun ve Fermanlarda Tezkiye}

1840 tarihli Ceza Kanunu'nun 3. Maddesinde “.... şahidler dahi kemâl-i dikkatle tezkiyesi neticesi.." 13 denilerek şahitlerin bu madde özelinde adam öldürme davalarında tezkiyelerinin dikkatle yapılması emredilmiştir. 1851 tarihli Ceza Kanunu'nun 2. ve 3. maddesinde de bu hüküm aynen korunmuştur. ${ }^{14}$

1855 tarihli Bi'l-Umûm Mehâkim-i Şer'iyye Hakkında Müceddeden Kaleme Alınan Nizâmnâmenin 61. maddesine göre şer'iyye mahkemelerinde görülecek davalarda mahkeme dışında tezkiye memurlarınca yapılacak şahitlerin tezkiyesi için 25 kuruştan 150 kuruşa kadar

7 SERAHSI, C.16, No:88; ALİ HAYDAR, C.4, s.3090, 3092; BİLMEN, Ömer Nasuhi, Hukuk-ı İslâmiyye ve Istllahat-ı Flkhiyye Kamusu, Bilmen Yayınevi, İstanbul, 1970, C.8, s.153; ZUHAYLİ, C.8, s.309.

8 MAVSILİ, C.2, s.229-230; DAMAD, C.4, s.490-491; TEHANEVI, Zafer Ahmed b. Latîf el-Osman, I'laü's Sünen, (Hadislerle Hanefi Flkhı), çev. Macit Bilge, Misvak Neşriyat, İstanbul, 2014, C.16, s.18-19; BAŞOĞLU, s.77.

9 DAMAD, C.4, s.491; FETAVA-YI HINDIYYE, C.7, s.80; BEHNESİ, Ahmed Fethi, Nazariyyetü'l-isbât fi'lfikhi'l-cinaiyyi'l-İslami, Beyrut, Dârü’ş-Şurûk, 1983, s.50.

10 BAYINDIR, s.184; AYDIN, s.180.

11 MAVSILİ, C.2, s.231; DAMAD, C.4, s.491; FETAVA-YI HINDDIYYE, C.7, s.81,82; YILDIZ, Kemal, İslam Yargılama Hukukunda Şahitlik, Hâcegân Akademi Kitaplığı, İstanbul, 2005, s.133.

12 HAMIDULLAH, Muhammed, İslam Peygamberi, çev. Mehmet Yazgan, Beyan Yayınları, İstanbul, 2014, No: 1562, s.776; ÖZEN, Şükrü, "Kadı Şureyh”, DİA, C.24, İstanbul, 2001, s.120.

13 AKGÜNDÜZ, Ahmet, İslam ve Osmanlı Hukuku Külliyatı, Osmanlı Araştırmaları Vakfı Yayınları, İstanbul, 2012, C.I, s.605.

14 AKGÜNDÜZ, C.I, s.614. 
tezkiye harcı alınması öngörülmüştür. Diğer maddelerde ise memur görevlendirmeye gerek olmayan durumlarda bu harcın alınmayacağı belirtilmiştir. ${ }^{15}$

1866 yılında çıkarılan bir fermanla, gerek gizli ve gerek açık olarak şâhitleri tezkiye edenlerin ve babalarının isimleri ile adresleri ve meşgul oldukları işlerin, sicillerde yazılmaya başlanması emredilmiştir. ${ }^{16}$

1879 tarihli Usul-1 Muhakemat-1 Cezaiye Kanununda şahitlerin tezkiyesi ile ilgili hüküm bulunmazken ${ }^{17}$ ayn1 tarihli Usul-1 Muhakemat-1 Hukukiye Kanununun 89. Maddesinde: "Şehadetin nisabı ve keyfiyet-i edası ve şurut-u esasiyesi ve davaya muvafakatı ve şahitlerin ihtilaf ve eda-i şehadetten sonra tezkiyeleri veyahut şehadetten nükulları hususları Mecelle-i Ahkâm-ı Adliyenin kitab-ı beyyinatına tevfik olunur" 18 denilerek şahitlerin tezkiyesi ile ilgili durumlarda Mecelle hükümlerinin esas alınacağı belirtilmiştir.

1907 tarihli bir belgeye göre nahiye meclislerinin adli ve sulhi vazifelerini mübeyyin nizamnamenin tezkiye-i şuhud hakkındaki özel faslının 33. maddesinin hükmü mahkemelerin diğer kısımlarında mer'i ve cari olan Mecelle-i Ahkâm-1 Adliye'nin ilgili maddesinin mündericatına muhalif olduğundan gereğinin icrası emredilmiş ${ }^{19}$ yani şahitlerin tezkiyesi ile alakalı Mecelle hükümlerine aykırı bir kanunname hükmünün geçerli olmayacağı düzenlenmiştir.

1917 tarihli Usul-1 Muhakeme-i Şer'iyye Kararnamesinde de şahitlerin tezkiyesi ile ilgili bir hüküm bulunmamaktadır. ${ }^{20}$

Tanzimat dönemindeki bu kanunlardan anlaşıldığı üzere şahitlerin tezkiyesi ile ilgili Mecelle-i Ahkâm-1 Adliye kabul edilinceye kadar klasik dönemden farklı uygulamalar bulunmamaktadır. $\mathrm{Bu}$ dönemde sadece 1866 yılındaki fermanda müzekkilerin ve onların babalarının isimlerinin, adresleri ve mesleklerinin sicilde yazılmaya başlanması söz konusudur. Mecelle-i Ahkâm-1 Adliye'nin tezkiye ile ilgili hükümleri kabul edildikten sonra ise bu hükümler geçerlidir ve bu hükümleri ilga eden bir kanuni düzenleme de bulunmamaktadır.

\section{B. Mecelle-i Ahkâm-ı Adliyye'de Tezkiye}

Şahitlerin tezkiyesi Mecelle'nin on beşinci kitabı olan Kitabü'l-Beyyinat ve't-Tahlif'in altıncı faslı olan Tezkiye-i Şuhud başlığında düzenlenmiştir. Bu fasıl Mecelle'nin 1716-1726. maddeleri arasındadır.

Mecelle-i Ahkâm-1 Adliyye hukuk yargılaması ile ilgili hükümleri kapsadığından bu hüküm de hukuk yargılamalarında söz konusu olmaktadır. Ulema tarafından ittifak olunan görüşe

15 AKGÜNDÜZ, C.I, s.933.

16 BOA, A.\}MKT.MHM., 365/13, H. 05.06.1283; AKGÜNDÜZ, C.I, s.841.

${ }^{17}$ Kanunun 268. Maddesinde “... Reis şahitlere isim ve şöhret ve sin ve sanatlarını ve daimi veya muvakkat ikametgâhların ve ithamnamede beyan olunan cürmün vukuundan evvel müttehemi tanlyıp tanımadıklarını ve mütteheme ve yahut müdde-i şahsiye bir güna karabetleri olup olmadlğını ve olduğu takdirde ne derecede bulunduğu ve müttehemin ve yahut müdde-i ş̧ hsinin hizmetinde bulunup bulunamadıklarını sual edecek ve badehu şahitler şifahen icra-yl şahadet eyleyeceklerdir." hükmü bulunmaktadır. GÖKCEN, Ahmet, "1296 (1879) Tarihli Usul-1 Muhakemat-1 Cezaiye Kanun-1 Muvakkatı", SÜHFD, C:4, Sy:1-2, 1994, s.246-247. Bu hüküm her ne kadar şahitlerin tezkiyesine yakın görünse de tam olarak tezkiyede uygulanacak usule uygun görünmemektedir.

18 Usul-1 Muhakemat-1 Hukukiye Kanun-1 Zeyli, Kader Matbaası, Dersaadet, 1329, s.35.

19 BOA, BEO, 3191/239272, H. 18-10-1325.

20 Bu kararname ile ilgili ayrıntılı bilgi için bkz. AKMAN, Ahmet, "Usul-1 Muhakeme-i Şer'iyye Kararnamesi ve Tahlili”, Basılmamış Yüksek Lisans Tezi, MÜSBE, İstanbul, 1985. 
göre ceza yargılamasındaki had ve kısas davalarında hâkim şahitleri tezkiye ettirmek zorundadır. Yani bu davalarda şahit olarak dilenecek kişiler hakkında, aleyhinde ifade verdikleri tarafça olumsuz bir görüş bulunsun veya bulunmasın yahut hâkim bu şahitlerin adil olup olmadıklarını kendi şahsi bilgisine dayanarak bilsin bilmesin, şahitlerin ifadelerini hükme esas alabilmek ve bu şahitlerin adil olup olmadıklarını belirlemek için alenen veya sırren tezkiye yapmalıdır.

Maddeleri teke tek ele alacak olursak:

Madde 1716: "Şahidler şehadet ettikde hâkim, meşhudun-aleyhten ne dersin, bunlar şehadetlerinde sadık mudırlar yoksa değil midirler diye sual eder."

Şahitler mahkemede ifade verdikten sonra aleyhine ifade verdikleri tarafa hâkim bu ifadelere bir diyeceği olup olmadığını sorar. Eğer bu taraf şahit ifadelerine itiraz etmez ve şahitlerin adil olduklarını, sözüne güvenilir kimseler olduklarını söylerse hâkim bu tarafın aleyhine hüküm verir. Çünkü bu durumda taraf iddiaları kabul etmiş olur ve hüküm de ikrara dayanılarak verilir. ${ }^{21}$ Ancak aleyhinde ifade verilen taraf tanıkların ifadelerine itiraz eder veya şahitlerin adil olmadıklarını iddia ederse şahitler tezkiye edilmeden hüküm verilemez. ${ }^{22}$

Madde 1717: "Şahidlerin gerek sirren ve gerek alenen mensub olduklar cânibden yani talebe-i ulûmdan ise sakin olduklar medrese müderrisi ile mu'temed ahalisinden ve askeriyeden ise taburu zabitân ve katiblerinden ve ketebeden ise kalemi zabitân ve hulefasindan ve tüccardan ise tüccarın mu'teberanindan ve esnaftan ise kethüdaslyla lonca ustalarindan ve sunuf-ı saireden ise mahalle ve karyelerinin mevsuk ve mü'temen ahaliinden tezkiye olunur."

$\mathrm{Bu}$ maddeye göre sırren ve alenen yapılacak tezkiyede şahitler ne iş yapıyorlarsa $\mathrm{o}$ iş arkadaşlarından sordurulur. Yani öğrenciler öğretmenlerinden, askerler komutanlarından memurlar amirlerinden, tüccar ve esnaflar kendi odalarındaki meslektaşlarından bunlara mensup olmayanlar ise ikamet ettikleri mahallelerindeki emin ve güvenilir kimselerden sordurulur. ${ }^{23}$

Mecelle şarihi Ali Haydar Efendi maddede geçen mu’temed, mevsuk ve mü'temen müzekki olabilmek için birtakım şartlar olduğunu belirtmiştir. Birinci şarta göre müzekki olacak kişi adil, şahitlerin durumlarını bilen, fakir olmayan kişilerden olmalıdır. Fakir olmaması rüşvet alması ihtimalinin önüne geçmek içindir. Bu şartı sağlayan Müslüman müzekkiler gayrimüslim şahitleri tezkiye edebilirler. İkinci şarta göre müzekki ile şahit arasında bilinen düşmanlık varsa bu müzekkinin tezkiyesi kabul edilmez. Üçüncü şarta göre şahitlerden birisi diğerini tezkiye edemez. Yani bir davada dinlenen şahitlerden birinin adil olduğu tezkiye sonucu ortaya çıktıktan sonra adaleti bilinmeyen diğer şahidi adil olan şahit tezkiye edemez. Kendi şahitliğinin boşa gitmemesi için böyle bir işi yapabilmesi ihtimali vardır. ${ }^{24}$

Tezkiyeyi yapacak olan müzekkiler cinsiyeti konusundaki kurala göre kadın şahitleri kadın müzekkiler tezkiye edebilir; çünkü kadınların hemcinslerinin ahvalini daha iyi bilmeleri

21 ALİ HAYDAR, C.4, s.3090-3091; TÜRKZADE, Hafiz Mehmed Ziyâeddin Efendi, Mecelle-i Ahkâm-1 Adliyye Şerhi, Kasbar Matbaası, Dersaadet, 1312 s.1080-1081; HACI REŞiT PAŞA, Ruhu'l-Mecelle, Dersaadet, 1328, C.8, s.69.

22 ALİ HAYDAR, C.4, s.3092; TÜRKZADE, s.1081. Aleyhine ifade verilen tarafin şahitleri ifade vermeden önce ta'dil etmelerinin bir hükmü yoktur. BİLMEN, C.8, s.153.

23 TÜRKZADE, s.1082; HACI REŞiT PAŞA, C.8, s.74.

24 ALİ HAYDAR, C.4, s.3094. 
normaldir. ${ }^{25}$ Davanın tarafları belirli bir erkeğin tezkiyesinin yeterli olması konusunda anlaşırlarsa, tarafların şahitlerini bu müzekkinin tek başına tezkiye etmesi yeterlidir. ${ }^{26}$ olunur."

Madde 1718: "Strren tezkiye istılah-ı fukahada mesture ta'bir olunur varaka ile icra

$\mathrm{Bu}$ maddeye göre sirren tezkiye mesture ismi verilen bir belge ile yapılır. Bu belgeye mesture ismi verilmesi gizli olarak müzekkilere gönderilmesi dolayısıyladır. Hâkim bu belgeye tarafların isimlerini, dava konusunu, şahitlerin isimlerini, varsa lakaplarını, ne işle meşgul olduklarını, eşkâllerini, ikametgâhlarını, baba ve dede isimlerini şahitlerin kimliklerinin başkalarıyla karıştırılmasına imkân vermeyecek şekilde yazar. Bu belgeyi kapalı bir zarfa koyup mühürler ve müzekkilere gönderir. ${ }^{27}$

Madde 1719: "Mesturede müzekkiler tarafindan şahidler adil ve makbulü’ş-şehade diye yazllmayıp da adil değillerdir, yahut hallerini bilmeyiz veya mechulü'l-ahvaldir yahut Allah bilir gibi sarahaten veyahut delaleten cerhi ifade eder bir söz yazllmış olur veyahut hiçbir şey yazılmaksızın mesture mahtûmen hâkime iade olunur ise hâkim ol şahidlerin şehadetini kabul etmez."

$\mathrm{Bu}$ maddeye göre sırren tezkiyenin yapılacağı mesturenin gönderildiği tezkiyeyi yapacak olan müzekkiler, bu mestureye şahitler hakkında olumsuz ifadeler yazarlarsa veya şahitlerin durumlarını bilmediklerini belirtirlerse veya hiçbir şey yazmadan mestureyi hâkime geri gönderirlerse hâkim söz konusu şahitlerin şahitliklerini kabul etmez.

Madde 1720: "Alenen tezkiye bu vechile icra olunur ki, müzekkiler huzur-ı hâkime celb ile müterâfi'ân hâzır oldukları halde şahidler tezkiye olunur."

Bu maddeye göre alenen tezkiyede müzekkiler hâkim huzuruna yani mahkemeye gelerek şahitleri tezkiye ederler. Sırren tezkiyedeki gibi mesture gönderilmesi usulü burada yoktur. Sirren tezkiye yapan müzekkilerin daha sonra aynı şahitleri alenen tezkiye etmelerinde bir engel yoktur. ${ }^{28}$

Madde 1721: "Sirren tezkiyede bir müzekki kâfi ise de ihtiyata riayeten lâ-ekall iki olmalıdır."

Sırren tezkiyede kural olarak bir müzekkinin şahidi tezkiye etmesi yeterlidir; ancak ihtiyaten iki müzekki olmalıdır. Burada Mecelle, bir müzekkinin yeterli olması konusundaki baskın Hanefi görüşünü yinelemekle beraber ihtiyaten iki kişi olmasını hususunu eklemiştir. Sırren tezkiye şehadet sayılmaz. Bu sebeple Ebu Hanife ve Ebu Yusuf’a göre sirren tezkiyede bir müzekki yeterlidir. Ancak İmam Muhammed'e göre iki müzekki gerekir. ${ }^{29}$

Tezkiye dini bir iş sayıldığı için müzekkilerde sadece adalet vasfı aranır. Dolayısıyla şahitliği kabul edilmeyen kazif suçundan ceza almış kişi, köle, çocuk ve âmâ dahi müzekki olabilir. Aynı şekilde akrabalık bağı sebebiyle birbirleri lehine şahitlik yapamayacak olanların birbirlerini

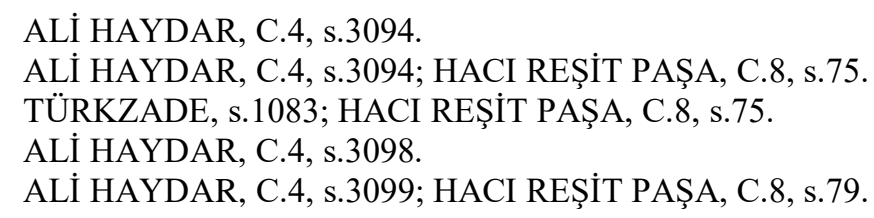


sırren tezkiye etmelerinde bir engel bulunmamaktadır. Aynı şekilde sırren tezkiyede "şahitlik ederim" lafzını kullanmak ve mahkeme huzurunda bulunmak şartları da yoktur. ${ }^{30}$

Madde 1722: "Tezkiye-i aleniyye şehadet kabilinden olup, şehadetin şurut ve nisabı bunda dahi muteberdir."

Aleni tezkiyede ise sırren tezkiyeden farklı olarak şehadet gibi sayılıp şahitlerde aranan şartlar ve yeter sayı bunda da aranacaktır. Buna göre aleni tezkiye yapan müzekki adil, ergin, hür, kazif suçundan ceza almamış olmalıdır. Ancak şehadette aranan "şahitlik ederim" lafzını kullanmak, aleni tezkiyede şart değildir. ${ }^{31}$

Madde 1723: "Bir hâkimin indinde bir husus zımnında adaleti sabit olan şahidler yine ol hâkimin huzurunda diğer bir hususa şehadet ettiklerinde, ĕger arası altı ay geçmemiş ise hâkim tekrar onları tezkiye ile meşgul olmaz."

Bu maddede daha önce olumlu olarak tezkiyeleri yapılan ve ifadeleri hükme esas alınan şahitlerin tekrar başka bir davada şahit olarak dinlenebilmeleri, ifadelerinin hükme esas alınabilmesi için tekrar tezkiyeye ihtiyaç duyulmayacağı sürenin altı ay olduğu belirtilmiştir. Yani şahitlerin olumlu olarak yapılan tezkiyelerinin son kullanma tarihi altı aydır. Altı ay sonra şahitlerin tekrar tezkiye edilmeleri gerekir. Bu altı ayın hesabında hicri aylar dikkate alınır. ${ }^{32}$

Madde 1724: “Gerek kable't-tezkiye ve gerek ba'de't-tezkiye meşhudun-aleyh def-i mağrem veya cerr-i meğnem gibi şehadetin kabulüne mani olur bir şey isnad ile şahidlere ta'n eder ise hâkim ondan beyyine taleb eder."

$\mathrm{Bu}$ maddeye göre tezkiyeden önce veya sonra şahidin aleyhinde ifade verdiği taraf şahit hakkında şahitliğin kabulüne engel olan bir hususun varlığını iddia ederse, hâkim bu engel hakkında aleyhine ifade verilen taraftan delil ister. Delil olmaksızın yapılan bu tür iddialar kabul edilemez. Örneğin şahidin karşı tarafın oğlu olduğunu iddia ederse bu iddiasını ispat etmelidir. Ancak bu konuda bir istisna bulunmaktadır. Aleyhinde ifade verilen taraf, dinlenen şahidin köle olduğunu iddia ederse, lehine ifade verilen taraf veya şahidin kendisi bu şahidin köle olmadığını ispat etmelidir. ${ }^{33}$

Madde: 1725: "Müzekkilerden bazısı şahidleri cerh ve bazısı ta'dil eylese cerh tarafi müreccah olarak hâkim onların şehadetleriyle hükmetmez."

Hâkimin şahitleri sordurduğu müzekkilerden bazıları şahidi olumlu olarak tezkiye derken bazısı olumsuz olarak tezkiye ederse, hâkim olumsuz tezkiyeyi esas alarak şahit ifadelerini hükme esas almaz. Burada şu hususu da belirtmek gerekir ki, müzekkilerden ikisi şahidi tadil yani olumlu tezkiye ederken biri cerh yani olumsuz tezkiye ederse olumlu tezkiye sonucuna ulaşılır. Eğer tadil edenlerle cerh edenler aynı sayıda veya cerh edenler çoğunluktaysa cerh esas alınır. Eğer bir müzekki tadil ederken bir müzekki cerh ederse hâkim üçüncü bir müzekkiye sordurup bunun vereceği cevabı esas alarak şahitlerin ifadelerini hükme esas alır veya almaz. ${ }^{34}$

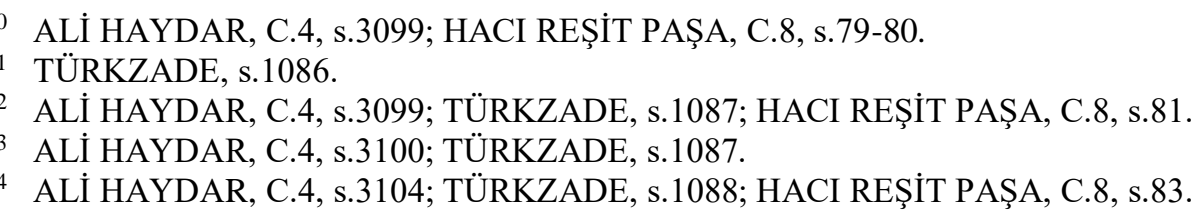


Madde 1726: "Muamelatta şahidler ba'de eda'i 'ş-şehadet fevt yahut gaib olsalar hâkim onları tezkiye ederek şehadetleriyle hükmedilebilir."

$\mathrm{Bu}$ maddeye göre hukuk davalarında ifade veren şahitler, kendileri hakkında tezkiye yaptırılmadan ölürlerse ve gaib olurlarsa hâkim bu şahitleri tezkiye ettirerek bunların verdiği ifadeyi hükme esas alabilir. Ceza davalarında ise şahitlerin hüküm verilinceye kadar duruşmalarda bulunmaları ve ifadelerinde sabit olmaları gerekir. ${ }^{35}$ Çünkü tanığın ifadesinden dönmesi her zaman mümkündür. Ayrıca bazı davalarda örneğin zina davasında şahit infazı başlatmakla yükümlü tutulmaktadır. Diğer bazı ceza davalarında da hükmün infazı boyunca infazı izlemeleri gerekmektedir. Ceza davaları sonucunda telafisi imkânsız zararların ortaya çıkması daha yüksek ihtimalde olduğu için bu esas getirilmiştir.

\section{C. Şahitlerin Tezkiyesine Getirilen Eleştiriler}

Ceride-i Adliye'nin birinci döneminin 1917 tarihli 154-155. sayısının 396 ila 402. sayfalarında yayınlanan "Tezkiye-i Şuhud Mesailine Dair"36 başlıklı ve yazarı bilinmeyen makalede verilen bilgiler şu şekildedir: Makalede tezkiye kurumunun Mecelle'de düzenlenen hükümlerinden bahsedilmiştir. Bununla beraber tezkiyeyi amacına uygun şekilde adil ve doğru bir şekilde yapacak müzekkilerin bulunmasının zor olduğundan bahsedilmiştir. ${ }^{37}$ Mecelle'de müzekkilerin şahitlerce bilinmemesi gerektiği kuralının benimsendiği ancak Mecelle'nin müzekkilerin kimler arasından seçileceğini saymakla sırren tezkiyenin yapılmasının amacını ve esasını ihlal ettiği belirtilmiştir. ${ }^{38}$ Sırren tezkiye sonucunun yazıldığı mestureyi lehine tanıklık yapan kişinin müzekkilere verdiğine bile rastlanmaktadır. Bu sebeple sırren tezkiyenin yapılma usulü fayda sağlamaktan ziyade yalan ve hileye başvuracak kişilerin elinde bir alet halini almıştır. ${ }^{39}$ Sırren tezkiyenin aleni tezkiye ile kuvvetlendirilmesi de gereksiz ve külfete yol açan bir yoldur; çünkü aleni tezkiye şahitlerin kimlik bilgilerinde bir karışıklık meydana gelmemesi için öngörülmüştür. ${ }^{40}$ Şahitlerin kimlik bilgilerinin ise şahitlik yapılmadan önce belirlenmesi gerekir. Şahitlerin adaletlerinin tespitinden ziyade tarafların kötü emellerine alet olan sırren ve alenen tezkiye usulü yerine daha basit ve faydalı bir usulün getirilmesi gerekir. ${ }^{41} \mathrm{Bu}$ konuda yapılması gerekenler şunlardır:

1- Şahitlere taraflardan bir itiraz olmazsa Ebu Hanife'nin içtihadı gibi tezkiye yapılmasına gerek yoktur.

2- Şahitlere taraflardan bir itiraz gelirse tarafların ortak olarak belirledikleri bir müzekki şahitleri tezkiye etmelidir.

3- Taraflar ortak olarak bir müzekki tayin edemezlerse şahitlerin durumuna bakacak olan hâkim, tezkiyeye ihtiyaç olup olmadığına karar vermelidir.

35 ALİ HAYDAR, C.4, s.3104.

36 Makalenin tam künyesi: “Tezkiye-i şuhud mesailine dair”, Anonim, Ceride-i Adliye, Sene: 7, Sy: 154-155, 1332, s.396-402.

37 “Tezkiye-i Şuhud Mesailine Dair", s.397-398.

38 “Tezkiye-i Şuhud Mesailine Dair”, s.399.

39 “Tezkiye-i Şuhud Mesailine Dair”, s.400.

40 “Tezkiye-i Şuhud Mesailine Dair”, s.400-401.

41 “Tezkiye-i Şuhud Mesailine Dair”, s.401. 
4- Hâkim bu karar sonucunda tezkiyeye gerek olduğuna karar verirse belirli kişilerle bağlı olmayıp güvendikleri kişileri müzekki olarak belirlemelidir.

5- Gerek tarafların ortaklaşa belirledikleri gerekse hâkimin atadığı müzekkilerin yaptıkları tezkiye kesin olup buna itiraz veya ikinci bir tezkiye yapılmamalıdır.

6- Hâkimlere verilecek takdir hakkının neticesinde şahitlerin dinlenmesi usulü konusunda kendisine bir yetki verilmelidir.

7- Şahitlerin tezkiyesine ne suretle olursa olsun lüzum görüldüğü takdirde alenen ve sırren tezkiye gibi bir usule gerek olmayıp duruma göre mahkeme huzurunda sözlü veya yazılı şekilde tezkiyeden birisi uygulanmalıdır.

8- Tezkiyeyi yapacak müzekkilerde şahitlerde aranan şartlar veya yeter sayı aranmamalıdır.

9- Şahidin kimlik bilgisini şüpheye yol açmayacak şekilde belirlemek hâkimin görevi olduğu için düşük bir ihtimalle ortaya çıkabilecek şahidin kimliğinde şüpheye düşülmesi halinde şahidin müzekki ile görüştürülerek tezkiye yapılmasına gerek duyulmamalıdır.

10- Her şahsın üslubu farklı olduğu için müzekkilerin mestureye verecekleri cevaplarda "adildir" "makbulü'ş-şehade" gibi ifadelerin aranılması yoluna gerek duyulmadan "iyi adamdır" "doğru adamdır" "şehadeti kabul edilebilir" gibi amacı ifade edecek her ifade kabul edilmelidir. ${ }^{42}$

$\mathrm{Bu}$ maddelerle hukuk yargılamasının kolaylıkla yapılması sağlanacak, dava ile alakası olmayan bir üçüncü kişi olan müzekkinin taraflar vasıtasıyla hükme müdahale edebilmesi önlenecek, şahitlerin adaletlerinin tespiti hâkimin takdirine bırakılacaktır. ${ }^{43}$

Ceride-i Adliye'nin ikinci döneminin 1922 tarihli ikinci sayısının 77 ila 79. sayfalarında bulunan "Tezkiye-i Şuhud" başlıklı Ankara kadısı İsmail Hakkı tarafından yazılan ikinci makalede $^{44}$ ise tezkiye kurumunun tarihçesi üzerinde çokça durulmuştur. İslam hukukunun kaynaklarında tezkiye kurumu hakkında bilgiler verilmiştir. İmam-1 Azam ile İmameyn arasındaki görüş ayrılığından bahsedilmekle beraber Şeyhülislam İbn Kemal gibi bazı âlimlerin sadece sırren tezkiyeyi yeterli bulduğu, bazı âlimlerin ise sadece alenen tezkiyeyi yeterli bulduğundan bahsedilmiştir. ${ }^{45}$ Makalede verilen diğer bilgiler şunlardır: Zamanımızda bir yöredeki zengin kişilerden olan şahidi maaşla çalışan imam ve muhtarın tezkiye etmesi çok abestir. Öyle ki zamanımızda imamlar kendi bölgelerinde kendilerinden sorulan bir şahidi olumsuz olarak tezkiye edecek durumda değillerdir. Velev ki olumsuz tezkiye yapacak olurlarsa hemen imamlik görevinden ve o yöreden kovulurlar. ${ }^{46}$ Kendi yanında çalışan bir memuru tezkiye edecek amirin yanında çalışan memuru olumsuz olarak tezkiye etmesi ise nezakete yakışmayan bir davranış olarak kabul edilmektedir. Bu örneklerden hareketle günümüzde tezkiyenin icrası bir gösteri

42 “Tezkiye-i Şuhud Mesailine Dair", s.401-402.

43 “Tezkiye-i Şuhud Mesailine Dair”, s.402.

44 Makalenin tam künyesi: İSMAIIL HAKKI, "Tezkiye-i şuhud”, Ceride-i Adliye, Sene:1, Sy:2, 1338, s.77-79.

45 İSMAİL HAKKI, s.77.

46 İSMAİL HAKKI, s.78. Mithat Cemal Kuntay'ın Üç İstanbul romanında da o tarihlerdeki tezkiye usulü şu şekilde açıklanmıştır: “..Adnan büsbütün şaşıyordu: Tezkiye ne kadar ucuzdu. Çilli Mahmut'un namuslu olması için imama yedi lira göndermişti. Rıdvan'ın namusu üç buçuk liraydı. Hafiz İsmail iki liraya namusluydu.... Dün şahit Rıdvan'la İsmail'in ve Mahmut'un tezkiye zarfları açılınca üç maskaranın namuslu olduğuna mahkeme ittifakla karar vermişti." KUNTAY, Mithat Cemal, Ü̧̧ İstanbul, 14.Bask1, Oğlak Yayınları, İstanbul, 2012, s.641,642. 
halindedir. ${ }^{47}$ Aleni tezkiye usulünde ise davanın taraflarından biri, şahitlerini mahkemeye ifade vermeye götürürken yanında iki başka kimseyi de götürür. Hâkim de bu kimselere şahitlerin adil olup olmadıklarını sorar. Oysa o taraf müzekki olarak götürdügü kimselere şahitlerin adil olduklarını söylemeleri için daha önceden tembihte bulunmuştur. Yargılamalar üzerinde bir çalışma yapılırsa aleni tezkiye usulünde şahitleri olumsuz olarak tezkiye eden müzekkilere rastlanmadığı görülecektir. ${ }^{48}$ Ceza yargılamasında âlimlerin ittifaken zorunlu olduğunu düşündügü tezkiyenin, ceza mevzuatında bulunmaması ve dolayısıyla terkinin herhangi bir zarara sebep olmadığı düşünüldüğünde hukuk yargılamasında merasim halini almasından mütevelli hâlihazırdaki şekliyle uygulanması hâkimleri ve hukukçuları üzmektedir. Dolayısıyla tezkiye usulünün zamanımızda bir faydası görülemediğinden yargılama usulünden kaldırılması ve yerine İslam'ın ilk dönemlerindeki gibi adaleti tesis eden ve halkın yararına olan basit usuller getirilmesi gerekir. $^{49}$

\section{SONUÇ}

Tanzimat dönemindeki kanunlarda tezkiye ile ilgili hükümler bütün olarak sadece Mecelle'de bulunmaktadır. Mecelle, Hanefi görüşü esas alınarak yazıldığı için Mecelle'nin "Tezkiye-i Şuhud" isimli on beşinci kitabının birinci babının altıncı faslında klasik devirdeki tezkiye ile ilgili esaslardan farklı hükümler bulunmamaktadır. Dolayısıyla tezkiye yüzyıllardan beri uygulanagelen esas ve kaideler çerçevesinde Tanzimat döneminde de uygulanmıştır. İşte bu hususta Osmanlı'nın son dönemi olan 1917 ve 1922 yıllarında Ceride-i Adliye'de yayınlanan iki makalede tezkiye usulünden eskisi gibi alınan verimin alınamadığı, usulleri eskidiği anlatılmıştır. $\mathrm{Bu}$ makale yazarlarının görüşlerine göre tezkiye kurumunda yapılacak olan değişiklikler ile bu kurumun daha faydalı, daha işlevsel hale geleceği öngörülmüştür.

Günümüz hukukunda ise uygulaması bulunmayan tezkiye usulü, şahitlere güvenin olmaması ve şahitlik delilinden alınması gereken faydanın tam olarak alınamaması sebebiyle pozitif hukukumuza uyarlanabilir. Bu sayede herkesin şahit olarak dinlenmesinin önüne geçilerek sadece adil ve sözüne güvenilir kimselerin şahitlik yapması sağlanacak, yalancı şahitliğin ve yalan beyan ile haksız hükmün ortaya çıkmasının engellenmesi sağlanabilir. Bu açıdan hukukumuzda yalancı tanıklık suçundan ceza almış ve cezası infaz edilmiş kimselerin bile şahitlik yapmasının önünde bir engel bulunmamaktadır. Belirli bazı suçlardan örneğin rüşvet, irtikâp, dolandırıcılık, yalancı tanıklık gibi suçlardan suçlu bulunup hükmü kesinleşmiş kişilerin şahitliklerinin hiç değilse belirli bir süre kabul edilmemesi bu açıdan yargıya ve şahitlere güvenin sağlanması açısından pozitif etkiye sebep olabilir düşüncesindeyim.

47 İSMAIL HAKKI, s.78.

48 ISMAIIL HAKKI, s. 78.

49 İSMAIIL HAKKI, s.79. 


\section{KAYNAKÇA}

“Tezkiye-i şuhud mesailine dair”, Anonim, Ceride-i Adliye, Sene: 7, Sy: 154-155, 1332, s.396-402.

Akgündüz, Ahmet, İslam ve Osmanlı Hukuku Külliyatı, Osmanlı Araştırmaları Vakfı Yayınları, İstanbul, 2012.

Akman, Ahmet, "Usul-1 Muhakeme-i Şer'iyye Kararnamesi ve Tahlili”, Basılmamış Yüksek Lisans Tezi, MÜSBE, İstanbul, 1985.

Ali Haydar, Hocaeminefendizade, Dürerü'l Hukkam Şerhu Mecelleti'l-Ahkâm, çev. Raşit Gündoğdu-Osman Erdem, DİB Yayınları, 2.Bask1, İstanbul, 2017.

Aslan, Nasi, İslam Yargılama Hukukunda “Şuhudü'l-Hal” Jüri Osmanlı Devri Uygulaması, Beyan Yayınlar1, İstanbul, 1999.

Aydın, Melikşah, Klasik Dönem Osmanlı Yargılama Hukukunda Tanıklı, Oniki Levha Yayıncılık, İstanbul, 2021.

Başbakanlık Osmanlı Arşivi, Sadâret Mektubî Kalemi Mühimme Kalemi (Odası) Belgeleri (A.MKT.MHM), 365/13, H. 05.06.1283.

Başbakanlık Osmanlı Arşivi, Babıali Evrak Odası Evrakı (BEO), 3191/239272, H-18-10-1325.

Başoğlu, Tuncay, “Tezkiye”, DİA, C.41, İstanbul, 2012.

Bayındır, Abdülaziz, İslam Muhakeme Hukuku Osmanlı Devri Uygulaması, İslâmi İlimler Araştırma Vakfı Yayınları, İstanbul, 1986. 1983.

Behnesi, Ahmed Fethi, Nazariyyetü'l-isbât fi'l-fikhi'l-cinaiyyi'l-İslami, Beyrut, Dârü"ş-Şurûk,

Bilmen, Ömer Nasuhi, Hukuk-ı İslâmiyye ve Istılahat-ı Fıkhiyye Kamusu, Bilmen Yayınevi, İstanbul, 1970.

Damad Tercümesi, Mecme'ul Enhur, çev. Mehmet Çelik, Yasin Yayınları, İstanbul, 2011.

Doğan, Hasan, "İslam Muhakeme Hukukunda Ta‘dîl ve Tezkiye", İslam Hukuku Araşttrmaları Dergisi, Sy.29, 2017, s.9-20.

Fetava-Yı Hindiyye, Fetava-yı Alemgiriyye, çev. Mustafa Efe, Huzur Yayınları, İstanbul, 2004.

Gökcen, Ahmet, "1296 (1879) Tarihli Usul-1 Muhakemat-1 Cezaiye Kanun-1 Muvakkatı”, Selçuk Üniversitesi Hukuk Fakültesi Dergisi, C:4, Sy:1-2, 1994, s.203-288.

Hacı Reşit Paşa, Ruhu'l-Mecelle, Dersaadet, 1328.

Hamidullah, Muhammed, İslam Peygamberi, çev. Mehmet Yazgan, Beyan Yay. İstanbul, 2014.

Hariri, İbrahim Muhammed, el-Kavaidu ve'd Davabitu'l Fikhiyyeti li-Nizami'l Kaza fi'l İslam, Umman, 1999.

İsmail Hakk1, "Tezkiye-i şuhud", Ceride-i Adliye, Sene:1, Sy:2, 1338, s.77-79.

Kelkit, Ömer Arif, “Kur’an’da Tezkiye” Basılmamış Yüksek Lisans Tezi, AÜSBE, Ankara, 1999.

Kuntay, Mithat Cemal, $\ddot{U} c ̧$ İstanbul, 14.Baskı, Oğlak Yayınları, İstanbul, 2012.

Mavsıli, Abdullah b. Mahmud b. Mevdud, el-ihhtiyar li- Ta'lîlî'l Muhtar, çev. Mehmet Keskin, Hikmet Neşriyat, İstanbul, 2013.

Messıck, Brinkley, "Evidence: From Memory to Archive", Islamic Law and Society, Vol. 9, No. 2, Evidence in Islamic Law (2002), s.231-270.

Özen, Şükrü, “Kadı Şureyh”, DİA, C.24, İstanbul, 2001. 
Serahsi, Ebu Sehl Ebu Bekir Muhammed b. Ahmed, Mebsut, ed. Mustafa Cevat Akşit, Gümüşev Yayınlar1, İstanbul, 2008.

Tehanevi, Zafer Ahmed b. Latîf el-Osman, I'laü's Sünen, (Hadislerle Hanefi Fıkhı), çev. Macit Bilge, Misvak Neşriyat, İstanbul, 2014.

Türkzâde Hafız Mehmed Ziyâeddin Efendi, Mecelle-i Ahkâm-1 Adliyye Şerhi, Kasbar Matbaası, Dersaadet, 1312.

Usul-1 Muhakemat-1 Hukukiye Kanun-1 Zeyli, Kader Matbaas1, Dersaadet, 1329.

Yıldız, Kemal, İslam Yargılama Hukukunda Şahitlik, Hâcegân Akademi Kitaplığı, İstanbul, 2005.

Zuhayli, Vehbe, İslam Fikhı Ansiklopedisi, ilmi müşavir Mehmet Emin Saraç, çev. Heyet, Risale Yayınlar1, İstanbul, 1994. 